\title{
Hydroxyapatite and a New Fibrin Sealant Derived from Snake Venom as Scaffold to Treatment of Cranial Defects in Rats
}

\author{
Marcelo Rodrigues da Cunha ${ }^{a, b *}$, Fernanda Araujo Menezes ${ }^{a}$, Geovane Ribeiro dos Santos ${ }^{b}$, \\ Clóvis Antônio Lopes Pinto ${ }^{b}$, Benedito Barravierac, Virginia da Conceição Amaro Martins ${ }^{d}$, \\ Ana Maria de Guzzi Plepis ${ }^{d}$, Rui Seabra Ferreira Junior ${ }^{c}$ \\ ${ }^{a}$ Laboratório de Anatomia, Centro Universitário Padre Anchieta - UniAnchieta, \\ Rua Bom Jesus de Pirapora, 100/140, CEP 13207-270, Jundiai, SP, Brasil \\ ${ }^{b}$ Departamento de Morfologia e Patologia Básica, Faculdade de Medicina de Jundiaí- FMJ, \\ Rua Francisco Telles, 250, CEP 13202-550, Jundiaí, SP, Brasil \\ ${ }^{c}$ Centro de Estudos de Venenos e Animais Peçonhentos - CEVAP, Universidade Estadual Paulista \\ “Julio de Mesquista Filho" - UNESP, Rua José Barbosa de Barros, 1780, \\ CEP 18610-307, Botucatu, SP, Brasil \\ 'Instituto de Química de São Carlos, Universidade de São Paulo - USP, \\ Av. Trabalhador São Carlense, 400, CEP 13566-590, São Carlos, SP, Brasil
}

Received: August 12, 2014; Revised: November 21, 2014

\begin{abstract}
Biomaterials are used as a promising alternative to bone grafts, including bioceramics whose composition resembles that of bone and fibrin sealants due to their hemostatic properties. The objective was to evaluate the repair of cranial defects in 40 rats, grafted with hydroxyapatite and a new fibrin sealant derived from snake venom. The animals were divided into four groups: $\mathrm{C}$ (control, no graft); Ha (hydroxyapatite); FS (fibrin sealant), and HaFS (hydroxyapatite and fibrin sealant). The animals were euthanized 2 and 6 weeks after surgery and wound area were submitted to analysis. After 2 weeks, immature bone was formed from the borders of the defect and in groups $\mathrm{Ha}$ and HaFS, few hydroxyapatite particles were surrounded by new bone. After 6 weeks, the new bone was mature and surrounded several hydroxyapatite particles, without connective tissue interposition and the volume of new bone was higher in HaFS group. The hydroxyapatite in combination with the new fibrin sealant accelerates bone repair.
\end{abstract}

Keywords: bioceramic, fibrin sealant, bone regeneration

\section{Introduction}

Autologous bone grafts have been the most common option in orthopedics and dentistry for reconstruction of the craniomaxillofacial skeleton and for bone reconstruction after trauma. These grafts have found wide acceptance because of their osteoinductive potential, providing cells that immediately trigger bone regeneration ${ }^{1}$. However, difficulties in obtaining these grafts and associated risks of injury have encouraged the development of new synthetic materials as bone graft substitutes ${ }^{2}$. An acceptable biomaterial should be degradable and resorbable, should serve as a scaffold for the growth of regenerated bone tissue, and should not cause any complication ${ }^{3}$. These features depend on both the physical and chemical properties of the material and should be compatible with the physiological reactions of bone ${ }^{4}$. In this respect, calcium phosphate ceramics are the biomaterials that show maximum chemical resemblance to bone ${ }^{5}$.

*e-mail: cunhamr@hotmail.com
Hydroxyapatite is a suitable bioceramic for bone repair due to its similarity to the mineral apatite of human bone. In addition, this biomaterial is atoxic and has a controllable microstructure in terms of pore $\operatorname{size}^{6}$. In view of its osteogenic properties, hydroxyapatite is widely used in bone reconstruction surgeries ${ }^{7-9}$. Another material used mainly for the regeneration of soft tissues is fibrin sealant, which serves as a scaffold for cell adhesion and growth, in addition to presenting hemostatic properties. Other applications of fibrin sealants include healing induction, cavity sealing, and as drug delivery systems ${ }^{10}$.

Commercial fibrin sealant is prepared as a mixture of human fibrinogen concentrate and reconstituted bovine thrombin in calcium chloride solution. Fibrinogen is converted into fibrin, producing a stable clot. This reaction is enhanced by the activation of factor XIII, which also participates in the synthesis of collagen, stimulating fibroblast proliferation and contributing to tissue healing. Factor XIII is also an excellent hemostatic agent ${ }^{11}$. However, the use of this commercial fibrin sealant is limited by the 
possibility of transmission of viruses such as parvovirus, hepatitis and $\mathrm{HIV}^{12}$. In addition, patients may develop antibodies against bovine thrombin ${ }^{13}$. In an attempt to overcome these difficulties, another sealant consisting of a thrombin-like enzyme extracted from snake venom and fibrinogen obtained from large animals to replace human components has shown excellent results in experimental studies on the regeneration of different tissues ${ }^{14-18}$, in mesenchymal cell cultures ${ }^{19}$, and in the healing of skin wound, venous ulcers and gingival graft sutures in humans $\mathrm{s}^{20,21}$. This new sealant is a biodegradable product that does not cause adverse reactions, does not contain human blood components, has good adhesive capacity, and does not transmit infectious diseases ${ }^{22}$. Considering these favorable properties, this new sealant should be explored clinically in different regenerative therapies. Therefore, the objective of the present study was to evaluate the osteogenic potential of a combination of hydroxyapatite and this new fibrin sealant in accelerating bone regeneration.

\section{Procedure}

\subsection{Hydroxyapatite}

\subsubsection{Synthesis}

Hydroxyapatite was synthesized from $1 \mathrm{~mol}$ $\mathrm{L}^{-1} \mathrm{Ca}\left(\mathrm{NO}_{3}\right)_{2} \cdot 4 \mathrm{H}_{2} \mathrm{O}$ and $0.6 \mathrm{~mol} \mathrm{~L}^{-1}\left(\mathrm{NH}_{4}\right)_{2} \mathrm{HPO}_{4}$ at $\mathrm{pH} 11\left(\mathrm{NH}_{4} \mathrm{OH}\right)$ in an atmosphere of $\mathrm{N}_{2}$. The suspension was shaken for $40 \mathrm{~h}$, filtered, washed in deionized water, and dried at $90^{\circ} \mathrm{C}$ for $15 \mathrm{~h}$. Granulometric sieves for particle size separation were used to obtain particles smaller than $200 \mathrm{~mm}$. The chemical reaction of hydroxyapatite formation can be written as follows:

$$
\begin{aligned}
& 10 \mathrm{Ca}\left(\mathrm{NO}_{3}\right)_{2}+6\left(\mathrm{NH}_{4}\right)_{2} \mathrm{HPO}_{4}+8 \mathrm{NH}_{4} \mathrm{OH} \rightarrow \\
& \mathrm{Ca}_{10}\left(\mathrm{PO}_{4}\right)_{6}(\mathrm{OH})_{2}+20 \mathrm{NH}_{4} \mathrm{NO}_{3}+6 \mathrm{H}_{2} \mathrm{O} .
\end{aligned}
$$

\subsubsection{Characterization}

Ca/P Ratio: $\mathrm{Ca}$ and $\mathrm{P}$ were determined by chemical conventional procedures by means of phosphomolybdate ${ }^{23}$, sodium EDTA.

Energy Dispersive X-Ray Analysis (EDX): were obtained in a EDX equipment LEO 440 (LEO Electron Microscopy Ltd, Cambridge, England), with an Oxford detector (Oxford Instruments Inc., Concord, USA) with $112 \mathrm{eV}$ resolution and samples previously coated with carbon at a distance of $20 \mathrm{~mm}$.

X-Ray Diffraction: Powder: X-ray diffractograms were performed in a Rigaku RU200B equipment, using $\mathrm{CuK} \alpha$ radiation, $50 \mathrm{kV}, 80 \mathrm{~mA}$, rate scaning $2^{\circ} \mathrm{min}^{-1}$ and $2 \theta$ between 5 to $80^{\circ}$.

Infrared Spectroscopy (FTIR): Infrared absorption spectrum was obtained from HA powder in $\mathrm{KBr}$ in a Bomen FTIR MB-120 spectrophotometer (Bomen Inc., Quebec, Canada), range from 400 to $4000 \mathrm{~cm}^{-1}$ with a resolution of $4 \mathrm{~cm}^{-1}$.

\subsection{Fibrin sealant}

The fibrin sealant was produced from a serine protease extracted from Crotalus durissus terrificus snake venom and fibrinogen was obtained from the cryoprecipitate of blood extracted from adult buffaloes. These components were reconstituted in a liquid state, generating a fibrin network. The fibrin sealant, under the scope of the Brazilian Patents BR 1020140114732 and BR 103602014 0114, was kindly provided by the Centro de Estudos de Venenos e Animais Peçonhentos (CEVAP, Botucatu, Brasil) $)^{19,24-26}$.

\subsection{Animals and study design}

Forty male Wistar rats (Rattus norvegicus) aged 12 weeks and weighing $330 \mathrm{~g}$ were used. For surgery, the animals were anesthetized by intramuscular injection of $1 \mathrm{mg} / \mathrm{kg}$ body weight xylazine (Virbac Brasil Ind. E Com., São Paulo, Brazil) and ketamine (Sespo Ind. E Com., Jacareí, São Paulo, Brazil) at a proportion of $1: 1^{27}$. The animals were placed in ventral decubitus and the skull was shaved. Next, an incision was made in the skin to expose the parietal bones. The periosteum was detached with an appropriate surgical instrument and a defect measuring $5 \mathrm{~mm}$ in diameter ${ }^{28}$ was created in the left parietal bone using a surgical bur in a micromotor (BELTEC LB-100, Araraquara, São Paulo, Brazil). The defect depth was $0.5 \mathrm{~mm}$, avoiding injury to the dura mater in brain (Figure 1).

The animals were divided into four groups of 10 animals each: group 1 (C), animals with a parietal bone defect not submitted to any treatment; group 2 (Ha), animals with a parietal bone defect filled with $8 \mathrm{mg}$ hydroxyapatite particles; group 3 (FS), animals with a parietal bone defect filled with $8 \mathrm{ml}$ fibrin sealant; group 4 (HaFS), animals with a parietal bone defect filled with $8 \mathrm{mg}$ hydroxyapatite and $8 \mathrm{ml}$ fibrin sealant.

The fibrin sealant was removed from the freezer at the time of use and its constituents mixed in a microtube together with hydroxyapatite. This mixture was then applied to animals (group 4). In groups 2 and 3, hydroxyapatite and fibrin sealant were applied directly into the animals, respectively.

After surgery, the periosteum and skin were repositioned and sutured. Five animals of each group were sacrificed 2 nd 6 weeks after surgery. The skullcaps were removed, photodocumented and radiographed for gross inspection of the bone defect. For morphologic analysis and quantification of newly formed bone at the defect site, histologic sections were obtained from the wound area and stained with hematoxylin-eosin. The study was approved by the Ethics Committee on Animal Experimentation of Centro Universitário Padre Anchieta, Jundiaí, São Paulo, Brazil (Protocol 01/2012).

\subsection{Analysis stereological and statistical}

The volume of a newly bone in 2 and 6 weeks in histologic images (magnification 100X) was calculated using a 100-point quadrilateral grid system coupled to the eyepiece of a light microscope. Bone neoformation was quantified based on the principle of Delesse using the formula $\mathrm{Vv}_{\mathrm{v}}=\mathrm{Pp} / \mathrm{Pt}(\%)$, where $\mathrm{Vv}_{\mathrm{v}}$ is the volume density or relative volume, $\mathrm{Pp}$ is the number of points (line intersection) on new bone, and Pt is the total number of points of the system ${ }^{29}$. The results were analyzed by Anova and the Tukey test $(\mathrm{p}<0.05)$ using the Bioestat 5.0 software. 

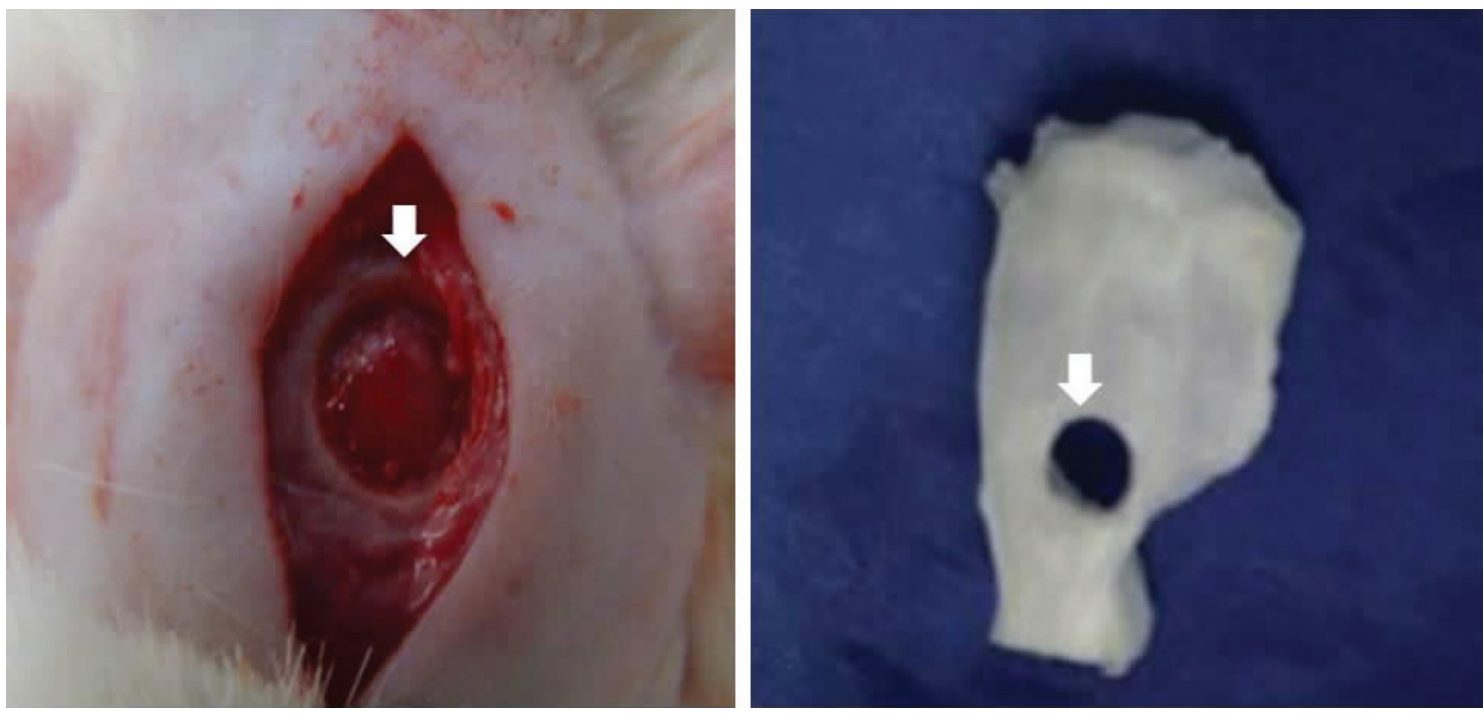

Figure 1. Upper view of the rat skull showing the experimentally created parietal bone defect (arrow).

\section{Results}

\subsection{Hydroxyapatite (HA)}

Synthesis of HA resulted in a white power and in its FTIR spectrum (Figure 2) peaks were observed at $3568 \mathrm{~cm}^{-1}\left(\mathrm{OH}^{-}\right), 1095,1032,962,603$ e $565 \mathrm{~cm}^{-1}\left(\mathrm{PO}_{4}^{-3}\right)$, $634 \mathrm{~cm}^{-1}\left(\mathrm{OH}^{-}\right)$, similar to values described for $\mathrm{HA}^{30}$. $\mathrm{X}$-ray diffraction (Figure 3 ) main peaks were detected with $\mathrm{d}$ values of $2.81,2.72,3.43$ and $1.84 \AA$, as described for HA [HA, JCPDS 9-0432] ${ }^{31}$. The crystallite size of the synthetized HA was measured by the (002) peak broadening, using Scherrer's equation ${ }^{32}$ :

$\mathrm{L}_{002}=\mathrm{K} \lambda / \mathrm{b} \cos (\theta)$

where $\mathrm{L}$ is the mean crystallite size, $\lambda$ the wavelength of X-ray radiation ( $\lambda=0.154056 \mathrm{~nm}$ for $\mathrm{CuK} \alpha$ radiation), $\mathrm{K}$ a constant related to the crystallite shape approximately equal to unity, $\beta$ the broadening of the 002 diffraction peak measured at half of its maximum intensity (in radians) and $\theta$ the Bragg diffraction angle $\left(^{\circ}\right)$. The estimate crystallite size of the hydroxyapatite crystals was $40 \mathrm{~nm}$.

$\mathrm{The} \mathrm{Ca} / \mathrm{P}$ ratio of $\mathrm{HA}$ determined by chemical procedures was 1.50. Compared to an expected value of 1.67 for stoichiometric HA, it suggests the formation of calcium deficient $\mathrm{HA}^{33}$. EDX technique showed that $\mathrm{Ca}$ and $\mathrm{P}$ were the only chemical elements present in the calcium phosphate ceramic. Although this technique is not quantitative the calculated value for $\mathrm{Ca} / \mathrm{P}$ ratio was 1.50 , similar to the chemical procedure.

\subsection{Histological analysis of the surgical area}

Macroscopic and radiologic analysis showed good definition and normal morphology of the wound area in all groups. There were no signs of pathological reactions indicating immune rejection of the biomaterials (Figures 4 and 5).

Histologic analysis of animals sacrificed 2 weeks after surgery revealed the presence of immature trabecular bone characterized by disorganized arrangement of several lacunae harboring osteocytes. New bone projected from the borders of the bone defect, a finding that was more pronounced in group HaFS-2. Also after 2 weeks, some hydroxyapatite particles were surrounded by new bone in groups Ha-2 and HaFS-2, but most of the bioceramic was still covered with connective tissue (Figure 4). Mature newly formed bone projecting from the borders of the defect was observed 6 weeks after surgery. In group Ha-6, hydroxyapatite particles located on the surface were surrounded by new bone. Bone neoformation was intensified in HaFS-6, in which several hydroxyapatite particles were completely surrounded by new bone in the absence of connective tissue interposition (Figure 5).

Significant difference was observed between all groups as shown in Figure 6 . The relative volume of new bone in the defect area after 2 weeks was $5.66 \pm 0.57,6.66 \pm 0.57$, $20 \pm 1.0$ and $21 \pm 1.0$ in groups C-2, Ha-2, FS-2, HaFS-2, respectively. After 6 weeks, the relative volume of new bone was $10.66 \pm 0.57,20.66 \pm 1.15,29.66 \pm 1.52$ and $53.66 \pm 0.57$ in groups C-6, Ha-6, FS-6, HaFS-6, respectively.

\section{Discussion}

The synthesis of HA resulted in the formation of calcium phosphate whose FTIR and X-ray diffraction spectra proved to be similar to $\mathrm{HA}^{30,31}$. The crystal size of synthetized HA was similar to that found for cortical bone being about $50 \mathrm{~nm}^{34}$. However, the $\mathrm{Ca} / \mathrm{P}$ ratio suggested the formation of a calcium-deficient HA

The objective of biomaterials is not only to fill the space of a defect, but also to stimulate a specific biological response that triggers tissue regeneration. This capacity depends on some intrinsic properties of the material, such as electron distribution, three-dimensional arrangement, molecular conformation, piezoelectric properties, porosity, and specific physicochemical properties. In addition, the material should serve as a scaffold that mimics 


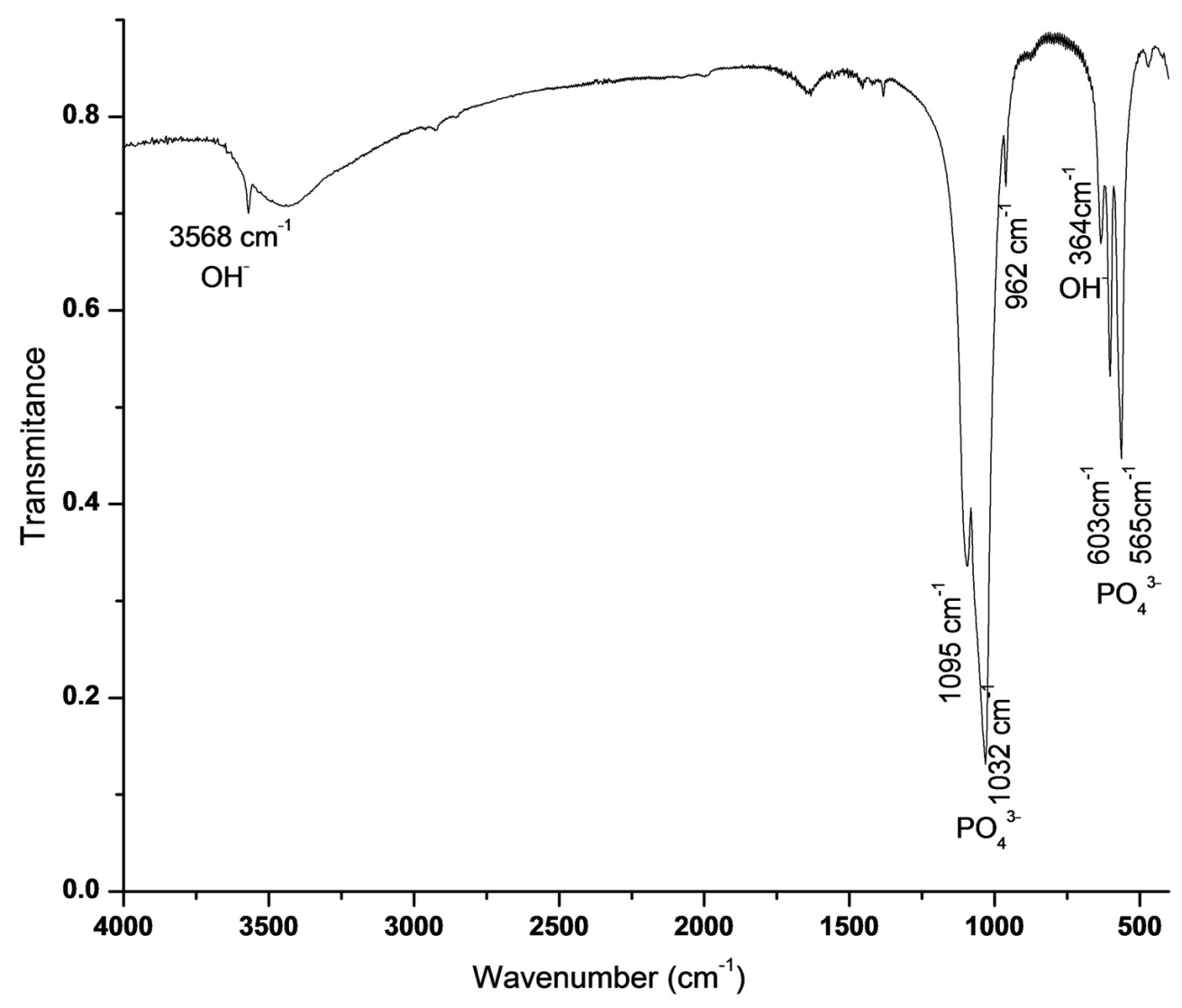

Figure 2. FTIR for synthetic hydroxyapatite.

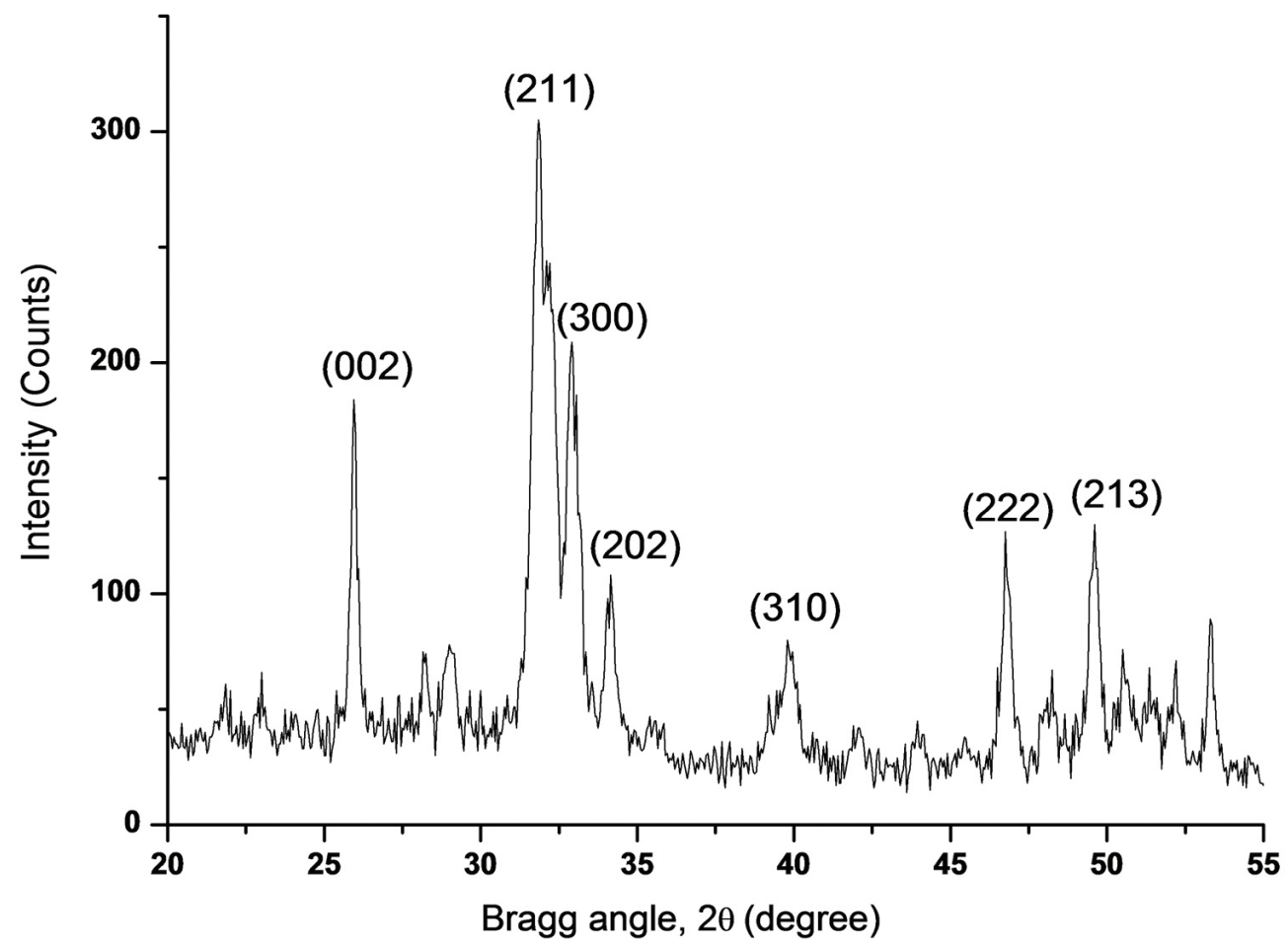

Figure 3. X-ray diffraction spectrum for synthetic hydroxyapatite. 

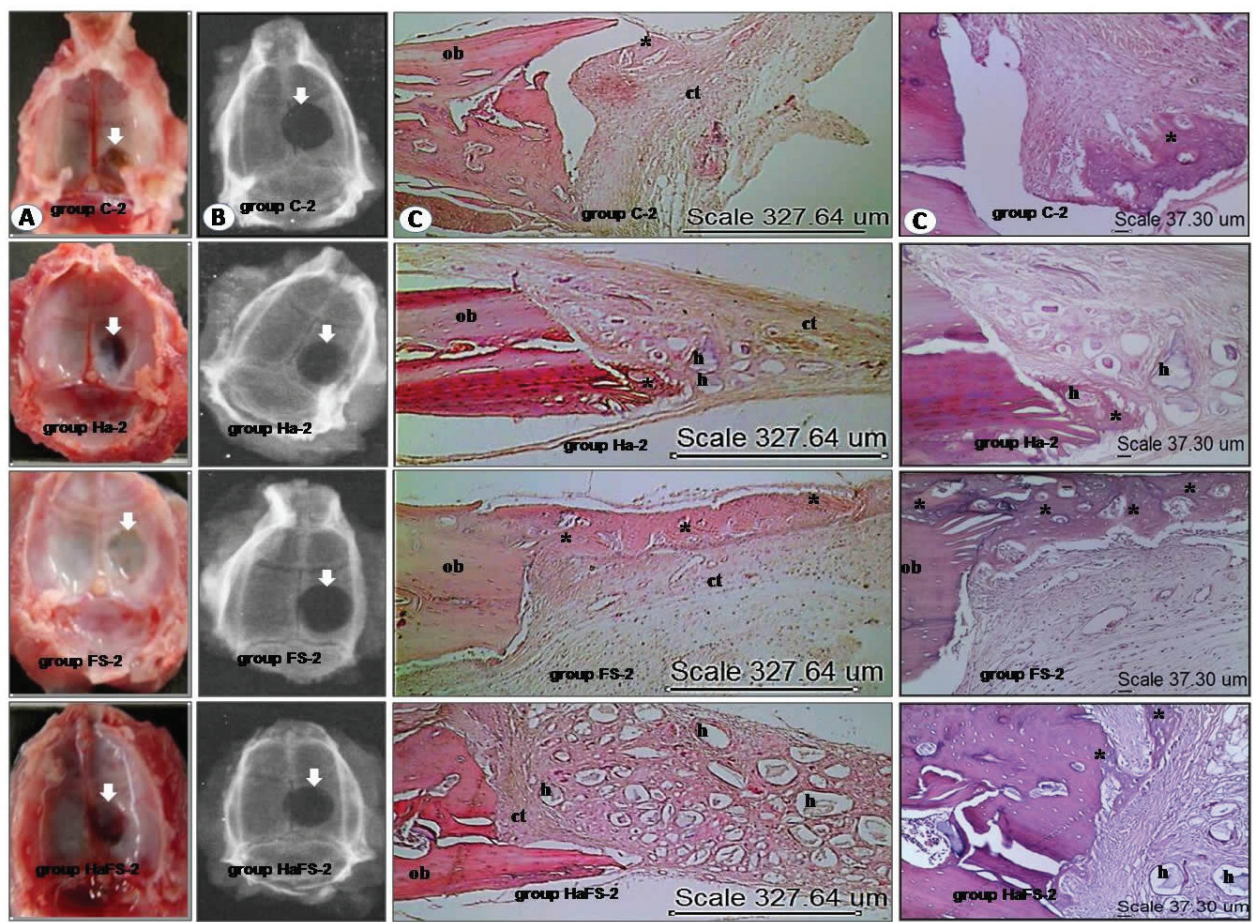

Figure 4. (A) Macroscopic, (B) radiologic and (C) histologic images obtained for animals of the four groups sacrificed 2 weeks (C-2, HA-2, FS-2, HAFS-2) after surgical creation of a parietal bone defect. In A and B, observe the absence of inflammatory signs and good definition of the bone defect area. In $\mathrm{C}$, a higher quantity of new bone $(*)$ projecting from the borders of the original bone $(\mathrm{ob})$ was observed in groups FS-2 and HAFS-2. Hydroxyapatite particles (h), connective tissue (ct).
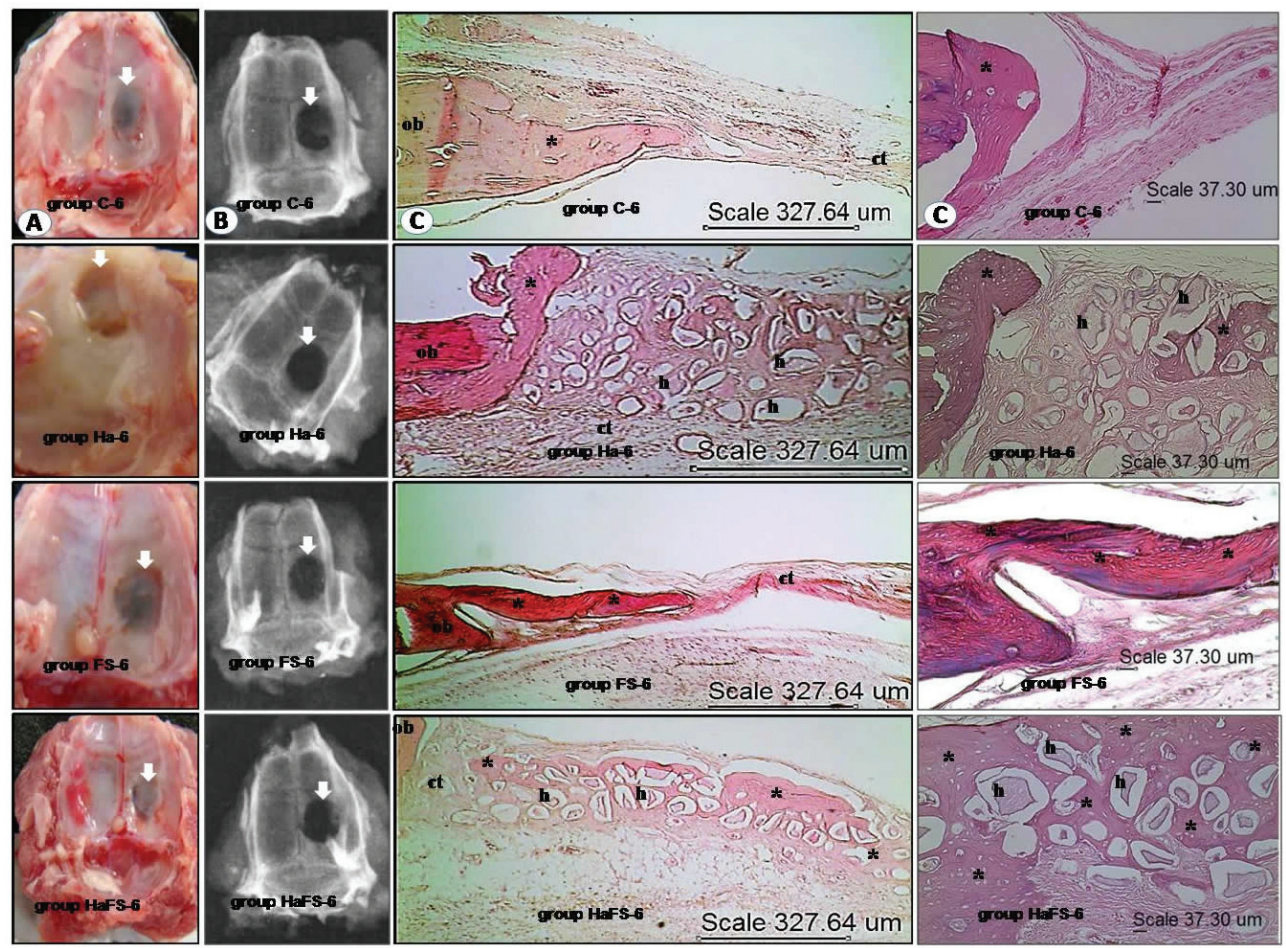

Figure 5. (A) Macroscopic, (B) radiologic and (C) histologic images obtained for animals of the four groups sacrificed 6 weeks (C-6, Ha-6, FS-6, HaFS-6) after surgical creation of a parietal bone defect. Note the absence of inflammatory signs. Microscopically, new bone was formed $(*)$ from the borders of the original bone $(\mathrm{ob})$ in all groups. This bone formation was more pronounced in group HaFS-2 in which most hydroxyapatite particles (h) were surrounded by new bone without connective tissue (ct) interposition. 


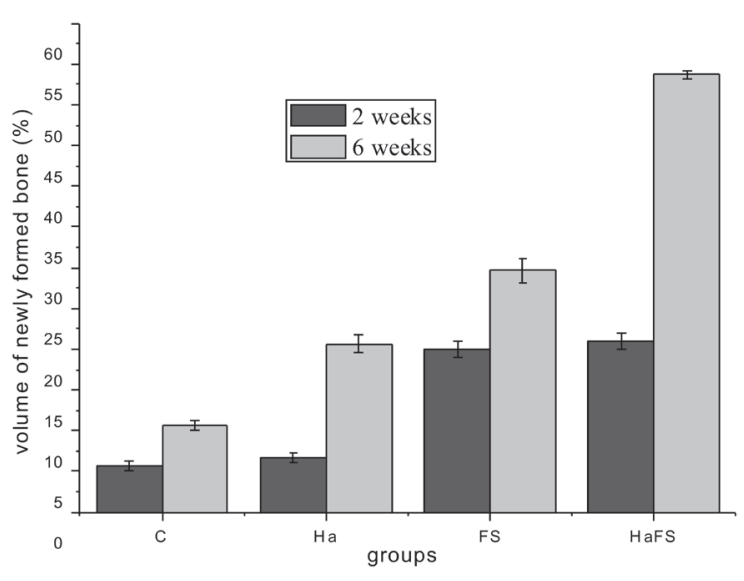

Figure 6. Morphometric analysis demonstrating the percentage of newly formed bone in 2 and 6 weeks.

extracellular matrix and permits cell adhesion, proliferation and differentiation. The biomaterials tested so far have advantages and disadvantages, as well as indications and contraindications, and the ideal material to stimulate bone reconstruction therefore needs to be determined ${ }^{35}$.

The present study demonstrated the biocompatibility of the new fibrin sealant with bone tissue since no macroscopic, radiologic or histologic signs of inflammation were observed that would characterize immune rejection of this biomaterial. An ideal scaffold should not only maintain, induce and restore biological functions, but should also have the right characteristics with respect to degradation, cellular uptake, cell binding, mechanical strength, and particularly non-immunogenicity ${ }^{35,36}$.

The promising results showing favorable bone growth in the groups treated with the new fibrin sealant are directly related to the spatial configuration of the sealant, which consists of a network of interposed fibrils and a porous structure that promotes the integration between live tissue and the implant. These properties are essential for cell growth and proliferation. In this respect, research demonstrated in vitro the migration and adhesion of mesenchymal cells to this snake venom-derived new sealant and thus can be used as an implant for bone repair ${ }^{19}$.

Okamoto et al. ${ }^{37}$ concluded that conventional fibrin sealant does not present adequate osteogenic activity when applied to bone defects created in rats. In contrast, in the present study significant growth of new bone in the defect area was observed in groups FS and HaFS, in which the bone defect was filled with the new fibrin sealant obtained from snake venom. This new sealant exhibited biofunctionality, causing no adverse biological reactions and favoring bone healing. In addition, osteogenesis at the bone defect site was more pronounced in group HaFS which received the new sealant combined with a bioceramic, especially at 6 weeks after surgery (HaFS-6). In this case, bone growth started from the border of the original bone and adjacent to the hydroxyapatite particles, with most particles being surrounded by new bone. These events significantly reduced the amount of connective tissue, with new bone occupying a greater volume in the defect area. This biological response is essential for bone regeneration.
According to Konig Junior ${ }^{35}$, it is important that the bioceramic is not resorbed too quickly so that the material can exert its osteoconductive and osteoinductive activity during bone repair. Schliephake and Kage ${ }^{38}$ concluded that the balance between degradation of the biomaterial and bone neoformation is very delicate and that chemical and cellular reactions during degradation may counteract bone formation. In this study, observed the presence of hydroxyapatite after 6 weeks of surgery with a proportional increase in bone formation and that the morphometric value of bone formed in group HaFS-6 was 5 times higher compared to C-6. These results demonstrate the osteoconductive capacity of hydroxyapatite and the excellent affinity of fibrin sealant in bone cell adhesion and proliferation.

Gasparotto et al. ${ }^{19}$ used a new fibrin sealant (FS) derived from snake venom to evaluated the in vitro growth and cell viability of mesenchymal stem cells (MSCs) and showed potential as a three-dimensional scaffold, maintaining cell survival without promoting differentiation. The ability of FS to capture and promote cell adhesion on its surface and the presence of cellular extensions into the interior of fibrin scaffold was demonstrated using transmission electron microscopy showing a uniform surface, forming an intensive 3D network of fibrin. With these observations of Gasparotto et al. ${ }^{19}$ suggests that good results obtained in this study regarding bone formation in the skull defect of the animals, is directly related to bone cell affinity in the new sealant.

The new fibrin selant is a three-dimensional scaffolding candidate capable of maintaining cell survival without interfering with differentiation. It might also be useful in drug delivery. The fibrin sealant has a low production cost, does not transmit infectious diseases from human blood and has properties of a suitable scaffold for stem cells because it permits the preparation of differentiated scaffolds that are suitable for every need ${ }^{19,24-26}$.

An inflammatory response and clot formation occurs during the first weeks of repair of bone defects grafted with porous biomaterials. Next, the proliferation of osteoprogenitor cells promotes the formation of trabecular bone 4 weeks after implantation of the biomaterial, thus completing the first stage of bone growth. The second stage is characterized by the remodeling of new bone and is influenced by the properties of the biomaterial ${ }^{35-40}$. In the present study, immature trabecular bone was observed in animals sacrificed after 2 weeks. Furthermore, there was no significant difference in the volume of new bone between groups C-2 and Ha-2 or between FS-2 and HAFS-2. This finding demonstrates the lack of significant osteoconductive capacity of the bioceramic in the early stage of bone repair, in contrast to what was observed in the groups receiving the new fibrin sealant. Cortical morphology and greater volume of new bone were observed in animals sacrificed after 6 weeks. In addition, during this period the volume of new bone increased gradually from groups C-6 to HaFS-6. This finding indicates that the osteogenic activity of the bioceramic is higher during the late stage of bone repair, but is still exceeded by that of the new fibrin sealant. The combination of these materials as done in group HaFS-6 resulted in the intensification of bone formation and a marked reduction in connective tissue, characterizing the principle of osseointegration and osteoregeneration. 


\section{Conclusion}

The new fibrin sealant derived from snake venom exhibited biofunctional and osteoconductive properties during bone repair. Its combination with hydroxyapatite provided osteogenic stimulation during the late stage of bone defect repair. The combination of these specific biomaterials is therefore an interesting option that should be explored in alternative therapies for treatment of bone lesions. However, 6 weeks were not sufficient for the complete repair of the bone defect, requiring more time for regeneration of the skull due to its intramembranous source and osteogenic slow action.

\section{References}

1. Miron RJ, Hedbom E, Saulacic N, Zhang Y, Sculean A, Bosshardt DD, et al. Osteogenic potential of autogenous bone grafts harvested with four different surgical techniques. Journal of Dental Research. 2011; 90(12):1428-1433. http://dx.doi. org/10.1177/0022034511422718. PMid:21940523

2. Keating JF and McQueen MM. Substitutes for autologous bone graft in orthopaedic trauma. The Journal of Bone and Joint Surgery. British Volume. 2001; 83(1):3-8. http://dx.doi. org/10.1302/0301-620X.83B1.11952. PMid:11245534

3. Mellonig JT. Porous particulate hydroxyapatite in a human periodontal osseous defect: a case report. The International Journal of Periodontics \& Restorative Dentistry. 1991; 11(3):217-223. PMid:1802878.

4. Borges APB, Rezende CMF, Ribeiro MFB, Melo EG and Nóbrega PI No. Hidroxiapatita sintética como substituto ósseo em defeito experimental provocado no terço proximal da tíbia em cão: aspectos à microscopia eletrônica de transmissão. Arquivo Brasileiro de Medicina Veterinária e Zootecnia. 2000; 52(6):616-620. http://dx.doi.org/10.1590/S010209352000000600011.

5. Lichte P, Pape HC, Pufe T, Kobbe P and Fischer H. Scaffolds for bone healing: concepts, materials and evidence. Injury. 2011; 42(6):569-573. http://dx.doi.org/10.1016/j.injury.2011.03.033. PMid:21489531

6. LeGeros RZ. Properties of osteoconductive biomaterials: calcium phosphates. Clinical Orthopaedics and Related Research. 2002; 395:81-98. http://dx.doi.org/10.1097/00003086200202000-00009. PMid:11937868

7. Shankar R, Singh D, Shaikh S, Singh G, Yadav A and Jain R. Bone regeneration in osseous defects using hydroxyapatite graft and the extent of ossification in osseous defects treated without grafts: a comparative evaluation. Journal of Maxillofacial and Oral Surgery. 2011; 10(2):123-126. http://dx.doi.org/10.1007/ s12663-011-0189-x. PMid:22654362

8. Burton DC, Carlson BB, Johnson PL, Manna BJ, RiaziKermani M, Glattes RC, et al. Backfilling of iliac crest defects with hydroxyapatite-calcium triphosphate biphasic compound: a prospective, randomized computed tomography and patientbased analysis. The Spine Journal: Official Journal of the North American Spine Society. 2013; 13(1):54-61. http://dx.doi. org/10.1016/j.spinee.2012.10.019. PMid:23168135

9. Franco GR, Laraia IO, Maciel AA, Miguel NM, Dos Santos GR, Fabrega-Carvalho CA, et al. Effects of chronic passive smoking on the regeneration of rat femoral defects filled with hydroxyapatite and stimulated by laser therapy. Injury. 2013;

\section{Acknowledgments}

The authors are grateful for funding received through FAPESP Proc. No. 2012/02689-3 (MRC), Proc. No. 2009/53846-9 (BB and RSFJr), FAPESP Proc. No. 2009/062800 (RSFJr), FAPESP Proc. No. 2012/08101-8 (RSFJr), CNPq Proc. No. 563582/2010-3 (BB), CAPES AUX-PE Toxinology 1219/2011 and Proc. No. 23038.000823/2011-21 (BB). Special thanks are also extended to the Centre for the Study of Venoms and Venomous Animals, CEVAP, UNESP, Brazil; Instituto de Química de São Carlos - USP; and NAPED/FMJ, CPIC/ CEUA/PIBIC/CNPq - UniAnchieta. RSFJr is a CNPq DTI fellow researcher (310207/2011-8).

44(7):908-913. http://dx.doi.org/10.1016/j.injury.2012.12.022. PMid:23340234

10. Alving BM, Weinstein MJ, Finlayson JS, Menitove JE and Fratantoni JC. Fibrin sealant: summary of a conference on characteristics and clinical uses. Transfusion. 1995; 35(9):783-790. http://dx.doi.org/10.1046/j.15372995.1995.35996029166.x. PMid:7570942

11. Thomazini-Santos IA. Fibrin adhesive from snake venom: the effect of adding epsilon-aminocaproic acid, tranexamic acid and apronitinin for coaptation of wound in rat skin incisions. Journal of Venomous Animals and Toxins. 2001; 7(1):148-149. http://dx.doi.org/10.1590/S0104-79302001000100011.

12. Hino M, Ishiko O, Honda KI, Yamane T, Ohta K, Takubo $\mathrm{T}$, et al. Transmission of symptomatic parvovirus B19 infection by fibrin sealant used during surgery. British Journal of Haematology. 2000; 108(1):194-195. http://dx.doi. org/10.1046/j.1365-2141.2000.01818.x. PMid:10651745

13. Barros LC, Ferreira RS Jr, Barraviera SRCS, Stolf HO, Thomazini-Santos IA, Mendes-Giannini MJS, et al. A new fibrin sealant from Crotalus durissus terrificus venom: applications in medicine. Journal of Toxicology and Environmental Health. Part B, Critical Reviews. 2009; 12(8):553-571. http:// dx.doi.org/10.1080/10937400903442514. PMid:20183534

14. Viterbo F, Thomazini IA and Giannini MJSM. Peripheral nerve repair with fibrin glue derived from snake venom. Acta Cirurgica Brasileira. 1993; 8(Suppl 2):85.

15. Sartori R Fo, Prestes NC, Thomazini IA, Mendes-Giannini MJ, Toscano E, Canavessi AMO, et al. Use of fibrin glue derived from snake venom in the testicular biopsy of rams. Journal of Venomous Animals and Toxins. 1998; 4(1):23-35. http://dx.doi. org/10.1590/S0104-79301998000100003.

16. Leite CVS, Naresse LE, Arantes HL, Lopes AF, ThomaziniSantos IA, Giannini MJS, et al. An evaluation by rat colon anastomosis of the efficacy of fibrin glue derived from snake venom. Journal of Venomous Animals and Toxins. 2000; 6(2):180-193. http://dx.doi.org/10.1590/S010479302000000200004 .

17. Rahal SC, Amaral MSP, Pai VD, Barraviera SRCS and Caporali EHG. Effect of fibrin glue derived from snake venom on the viability of autogenous split-thickness skin graft. Journal of Venomous Animals and Toxins including Tropical Diseases. 2004; 10(2):161-172. http://dx.doi.org/10.1590/S167891992004000200006.

18. Sampaio RL, Ranzani JJT, Brandão CVS, Thomazini-Santos IA, Barraviera B, Barraviera SRCS, et al. Use of fibrin glue derived from snake venom in the repair of deep corneal ulcers: experimental study in dogs. Journal of Venomous Animals and 
Toxins including Tropical Diseases. 2007; 13(4):857-873. http://dx.doi.org/10.1590/S1678-91992007000400014.

19. Gasparotto VPO, Landim-Alvarenga FC, Oliveira ALR, Simões GF, Lima-Neto JF, Barraviera B, et al. A new fibrin sealant as a three-dimensional scaffold candidate for mesenchymal stem cells. Stem Cell Research \& Therapy. 2014; 5(3):78. http:// dx.doi.org/10.1186/scrt467. PMid:24916098

20. Chiquito GCM. Comparison between suture and fibrin adhesive derived from snake venom for fixation of connective tissue graft in correction of marginal tissue recession. Journal of Venomous Animals and Toxins including Tropical Diseases. 2007; 13(2):559. http://dx.doi.org/10.1590/S167891992007000200014.

21. Barbosa MDS, Stipp AC, Passanezi E and Greghi SLA. Fibrin adhesive derived from snake venom in periodontal surgery: histological analysis. Journal of Applied Oral Science: Revista FOB. 2008; 16(5):310-315. http://dx.doi.org/10.1590/S167877572008000500002. PMid:19089226

22. Gatti M, Vieira LM, Barraviera B and Barraviera SRCS. Treatment of venous ulcers with fibrin sealant derived from snake venom. Journal of Venomous Animals and Toxins including Tropical Diseases. 2011; 17(2):226-229. http:// dx.doi.org/10.1590/S1678-91992011000200015.

23. Murphy J and Riley JP. A modified single solution method for the determination of phosphate in natural waters. Analytica Chimica Acta. 1962; 27:31-36. http://dx.doi.org/10.1016/ S0003-2670(00)88444-5.

24. Seabra Ferreira R. Autologous or heterologous fibrin sealant scaffold: which is the better choice? The Journal of Venomous Animals and Toxins Including Tropical Diseases. 2014; 20(1):31. http://dx.doi.org/10.1186/1678-9199-20-31. PMid:25075206

25. Barbizan R, Castro MV, Rodrigues AC, Barraviera B, Ferreira RS and Oliveira AL. Motor recovery and synaptic preservation after ventral root avulsion and repair with a fibrin sealant derived from snake venom. PLOS ONE. 2013; 8(5):e63260. http://dx.doi.org/10.1371/journal.pone.0063260. PMid:23667596

26. Iatecola A, Barraviera B, Ferreira RS Jr, dos Santos GR, Neves JI and da Cunha MR. Use of a new fibrin sealant and laser irradiation in the repair of skull defects in rats. Brazilian Dental Journal. 2013; 24(5):456-461. http://dx.doi.org/10.1590/01036440201302265. PMid:24474284

27. Do Prado Ribeiro DC, de Abreu Figueira L, Issa JPM, Dias Vecina CA, Josédias F and Da Cunha MR. Study of the osteoconductive capacity of hydroxyapatite implanted into the femur of ovariectomized rats. Microscopy Research and Technique. 2012; 75(2):133-137. http://dx.doi.org/10.1002/ jemt.21035. PMid:21761494

28. Rojbani H, Nyan M, Ohya K and Kasugai S. Evaluation of the osteoconductivity of $\alpha$-tricalcium phosphate, $\beta$-tricalcium phosphate, and hydroxyapatite combined with or without simvastatin in rat calvarial defect. Journal of Biomedical Materials Research. Part A. 2011; 98(4):488-498. http://dx.doi. org/10.1002/jbm.a.33117. PMid:21681941

29. Lacerda CAM. Whats is the interest of normal and pathologicalmorphological research to be quantitative? The exemple of the stereology. Brazilian Journal of Morphological Sciences. 1999; 16:131-139.

30. Rameshbabu N, Sampath Kumar TS and Prasad Rao K. Synthesis of nanocrystalline fluorinated hydroxyapatite by microwave processing and its in vitro dissolution study. Bulletin of Materials Science. 2006; 29(6):611-615. http:// dx.doi.org/10.1007/s12034-006-0012-3.

31. International Centre for Difraction Data - ICDD. Powder diffraction file 1994: PDF-2 Database Sets 1- 44. Newtown Square: ICDD; 1994.

32. Brundavanam RK, Poinern GEJ and Fawcett D. Modelling the crystal structure of a $30 \mathrm{~nm}$ sized particle based hydroxyapatite powder synthesized under the influence of ultrasound irradiation from X-ray powder diffraction data. American Journal of Materials Science. 2013; 3(4):84-90.

33. Ramesh S, Tan CY, Hamdi M, Sopyan I and Teng WD. The influence of $\mathrm{Ca} / \mathrm{P}$ ratio on the properties of hydroxyapatite bioceramics. In: Du S, Leng J and Asund AK. Proceedings of SPIE: International Conference on Smart Materials and Nanotechnology in Engineering; 2007; 6423:64233A.. http:// dx.doi.org/10.1117/12.779890.

34. Sato K. Mechanism of hydroxyapatite mineralization in biological systems. Journal of the Ceramic Society of Japan. 2007; 115(1338):124-130. http://dx.doi.org/10.2109/ jcersj.115.124.

35. Konig B Jr. Implantology and osseointegration. São Paulo: Roca; 2010. 360 p.

36. Billström GH, Blom AW, Larsson S and Beswick AD. Application of scaffolds for bone regeneration strategies: current trends and future directions. Injury. 2013; 44(Suppl 1):S28-S33. http://dx.doi.org/10.1016/S00201383(13)70007-X. PMid:23351866

37. Okamoto T, Alves-Rezende MC, Okamoto AC, Buscariolo IA and Garcia IR Jr. Osseous regeneration in the presence of fibrin adhesive material (Tissucol) and epsilon-aminocaproic acid (EACA). Brazilian Dental Journal. 1995; 6(2):77-83. PMid:8688661.

38. Schliephake H and Kage T. Enhancement of bone regeneration using resorbable ceramics and a polymer-ceramic composite material. Journal of Biomedical Materials Research. 2001; 56(1):128-136. http://dx.doi.org/10.1002/10974636(200107)56:1<128::AID-JBM1077>3.0.CO;2-L. PMid:11309799

39. Spector M, Harmon SL and Kreutner A. Characteristics of tissue growth into Proplast and porous polyethylene implants in bone. Journal of Biomedical Materials Research. 1979; 13(5):677-692. http://dx.doi.org/10.1002/jbm.820130502. PMid:479215

40. Weinans H, Huiskes R, van Rietbergen B, Sumner DR, Turner $\mathrm{TM}$ and Galante JO. Adaptive bone remodeling around bonded noncemented total hip arthroplasty: a comparison between animal experiments and computer simulation. Journal of Orthopaedic Research: Official Publication of the Orthopaedic Research Society. 1993; 11(4):500-513. http:// dx.doi.org/10.1002/jor.1100110405. PMid:8340823 